Survival of Ancient Landforms in a Collisional Setting as Revealed by Combined Fission Track and (U-Th)/He Thermochronometry: A Case Study from Corsica (France)

Author(s): Martin Danišík, Joachim Kuhlemann, István Dunkl, Noreen J. Evans, Balázs

Székely, and Wolfgang Frisch

Reviewed work(s):

Source: The Journal of Geology, Vol. 120, No. 2 (March 2012), pp. 155-173

Published by: The University of Chicago Press

Stable URL: http://www.jstor.org/stable/10.1086/663873

Accessed: 05/11/2012 01:27

Your use of the JSTOR archive indicates your acceptance of the Terms \& Conditions of Use, available at

http://www.jstor.org/page/info/about/policies/terms.jsp

JSTOR is a not-for-profit service that helps scholars, researchers, and students discover, use, and build upon a wide range of content in a trusted digital archive. We use information technology and tools to increase productivity and facilitate new forms of scholarship. For more information about JSTOR, please contact support@jstor.org. 


\title{
Survival of Ancient Landforms in a Collisional Setting as Revealed by Combined Fission Track and (U-Th)/He Thermochronometry: A Case Study from Corsica (France)
}

\author{
Martin Danišík, ${ }^{1,2,3, \star}$ Joachim Kuhlemann, ${ }^{1,4}$ István Dunkl, ${ }^{1,5}$ Noreen J. Evans, ${ }^{2,6}$ \\ Balázs Székely, ${ }^{1,7}$ and Wolfgang Frisch ${ }^{1}$
}

1. Institute of Geosciences, University of Tübingen, Sigwartstrasse 10, D-72076 Tübingen, Germany; 2. John de Laeter Centre for Isotope Research, Applied Geology, Curtin University of Technology, GPO Box U1987, Perth, Western Australia 6845, Australia; 3. Department of Earth and Ocean Sciences, University of Waikato, Private Bag 3105, Hamilton 3240, New Zealand; 4. Environment and School Initiatives, CH-5232 Villigen-ENSI, Switzerland; 5. Geoscience Center Göttingen, Sedimentology and Environmental Geology, Goldschmidtstrasse 3, D-37077 Göttingen, Germany; 6. Commonwealth Scientific and Industrial Research Organisation (CSIRO) Earth Science and Resource Engineering, 26 Dick Perry Avenue, Western Australia 6151, Australia; 7. Institute of Photogrammetry and Remote Sensing, Technical University Vienna, Gusshausstrasse 27-29, A-1040 Vienna, Austria

\begin{abstract}
A B S T R A C T
The age of high-elevation planation surfaces in Corsica is constrained using new apatite (U-Th)/He data, field observations, and published work (zircon fission track, apatite fission track [AFT] data and landform/stratigraphical analysis). Thermal modeling results based on AFT and (U-Th)/He data, and the Eocene sediments uncomformably overlapping the Variscan crystalline basement indicate that present-day elevated planation surfaces in Corsica are the remnants of an erosion surface formed on the basement between $\sim 120$ and $\sim 60 \mathrm{Ma}$. During the Alpine collision in the Paleocene-Eocene, the Variscan crystalline basement was buried beneath a westward-thinning wedge of flysch, and the eastern portion was overridden by the Alpine nappes. Resetting of the apatite fission track thermochronometer suggests an overburden thickness of $>4 \mathrm{~km}$ covering Variscan Corsica. Protected by soft sediment, the planation surface was preserved. In the latest Oligocene to Miocene times, the surface was re-exposed and offset by reactivated faults, with individual basement blocks differentially uplifted in several phases to elevations of, in some cases, $>2$ $\mathrm{km}$. Currently the planation surface remnants occur at different altitudes and with variable tilt. This Corsican example demonstrates that under favorable conditions, paleolandforms typical of tectonically inactive areas can survive in tectonically active settings such as at collisional plate margins. The results of some samples also reveal some discrepancies in thermal histories modeled from combined AFT and (U-Th)/He data. In some cases, models could not find a cooling path that fit both data sets, while in other instances, the modeled cooling paths suggest isothermal holding at temperature levels just below the apatite partial annealing zone followed by final late Neogene cooling. This result appears to be an artifact of the modeling algorithm as it is in conflict with independent geological constraints. Caution should be used when cross-validating the AFT and (U-Th)/He systems both in the case extremely old terrains and in the case of rocks with a relatively simple, young cooling history.
\end{abstract}

\section{Introduction}

Elevated planation surfaces are prominent landforms in many parts of the world (Penck 1925; Fairbridge and Finkl 1980; Twidale 1994; Gunnell 1998). Despite their frequency, their origin, time of

Manuscript received August 31, 2010; accepted November 16, 2011.

* Author for correspondence; e-mail m.danisik@waikato.ac .$n z$. formation, presumed persistence and longevity, and the modalities of preservation are often debated (Twidale 1998; Belton et al. 2004; Japsen et al. 2009). They typically occur in tectonically inactive regions such as continental shields or in passive margin settings (e.g., Australia, Africa, Laurasia), where they have been preserved since the Cretaceous or earlier (e.g., Twidale 1998, 1999; Belton et

[The Journal of Geology, 2012, volume 120, p. 155-173] @ 2012 by The University of Chicago. All rights reserved. 0022-1376/2012/12002-0003\$15.00. DOI: 10.1086/663873 
al. 2004; Danišík et al. 2010). In contrast, they are rarely preserved in tectonically active regions (Clark et al. 2006; Casas-Sainz and Cortes-Gracia 2002; Restrepo-Moreno et al. 2009). In orogenic belts they generally form in the postorogenic stage and thus typically represent relatively young features (e.g., Babault et al. 2005; Gunnell et al. 2009).

Elevated planation surfaces usually represent the oldest geomorphic elements in present-day landscapes. As prominent morphostratigraphic markers and excellent reference level indicators, elevated planation surfaces may have great application in landscape evolution studies, provided the absolute chronology of their formation can be reasonably established. This requires a multidisciplinary approach combining low-temperature thermochronology, cosmogenic nuclides methods, landscape analysis, and/or stratigraphy (e.g., Japsen et al. 2005, 2006, 2009; Bonow et al. 2007; RestrepoMoreno et al. 2009; Hetzel et al. 2011) and may require acceptance of some arbitrary (parsimonious or Occam's razor) assumptions in the absence of the desired data (Japsen et al. 2009).

Owing mainly to the latter, the concept of uplifted erosion surfaces as tools for constraining landscape evolution can be questioned. For instance, elevated planation surfaces might not have formed close to existing base level, as typically assumed (e.g., Summerfield 2000; Phillips 2002). In addition, even if planation surfaces did form close to a base level, this base level need not be the same as sea level (Brown et al. 2000). This would make the elevated erosion surfaces effectively useless in any attempt to constrain surface uplift (Summerfield 2005).

In this study, we investigate elevated planation surfaces on the island of Corsica, aiming to better understand the landscape development of the island and to formulate an integrated analysis of the burial and exhumation history. The planation surfaces are preserved at elevations $>2000 \mathrm{~m}$ asl (Rondeau 1961; Kuhlemann et al. 2005), but their age and genesis is still not adequately resolved. To resolve the question of their age, we apply a multidisciplinary approach using new apatite $(\mathrm{U}-\mathrm{Th}) / \mathrm{He}$ (AHe) data from the planation surfaces coupled with published zircon fission track (ZFT) and apatite fission track (AFT) data (Danišík et al. 2007) and interpretations from landform analysis (Rondeau 1961; Kuhlemann et al. 2005) and stratigraphy (Orszag-Sperber and Pilot 1976; Durand-Delga 1978; Rossi et al. 1980; Cubells et al. 1994; Egal 1992; Ferrandini and Loÿe-Pilot 1992). We also present some complexities in interpretation and ap- parent inconsistencies between the different results obtained. Finally we present a possible reconstruction of the morphotectonic evolution and refine the geodynamic and low-temperature cooling history of Corsica.

\section{Geological Setting}

Two geological domains are distinguished in Corsica: the Variscan and the Alpine (fig. 1A; DurandDelga 1978; Molli 2008). Variscan Corsica consists largely of Carboniferous to Permian granitoids and volcanic rocks (34-260 Ma) that were formed during the Variscan orogeny and post-Variscan extension (Cocherie et al. 1984; Durand-Delga 1984; Rossi and Cocherie 1991). The crystalline basement is overlain by sparsely preserved Mesozoic continental and marine sedimentary rocks. Variscan Corsica is cut by subvertical, southwest-northeast-trending faults that dictate the orientation of valleys.

Alpine Corsica is a complex stack of nappes derived from Jurassic oceanic crust and Jurassic to Paleogene sediments of the Ligurian-Piedmont Ocean and from the adjacent thinned continental margin of the European plate and its sedimentary cover (Durand-Delga 1978). These units were metamorphosed under high-pressure/low-temperature and middle-pressure/low-temperature conditions in the Late Cretaceous and Eocene. They were thrust onto the margin of Variscan Corsica in the Eocene (Caron et al. 1981; Mattauer et al. 1981; Gibbons and Horák 1984; Malavieille et al. 1998; Brunet et al. 2000).

Tertiary syn- and postcollisional successions are represented by the following: (i) Locally Upper Paleocene but mainly Lower to Middle Eocene foredeep flysch, which occurs along the border zone between Alpine and Variscan Corsica, contains detrital material from the Variscan basement and is several hundred meters thick (Durand-Delga 1978; Rossi et al. 1980; Egal 1992). In the northern and central areas of Corsica, the flysch was involved in the subduction process, as evidenced by blue amphibole, indicating metamorphic conditions of $P=0.5 \mathrm{GPa}$ and $\mathrm{T}=300^{\circ} \pm 50^{\circ} \mathrm{C}$ (Bézert and Caby 1988, 1989). Further to the south, the flysch is largely undeformed and devoid of metamorphic assemblages, and it shows onlap on the Variscan basement and the Alpine nappes (Egal 1992). (ii) Scarce Oligocene continental conglomerates occur on the west-southwest coast of the island (Ferrandini et al. 1999) and contain pebbles derived from local Variscan crystalline basement. (iii) There are 


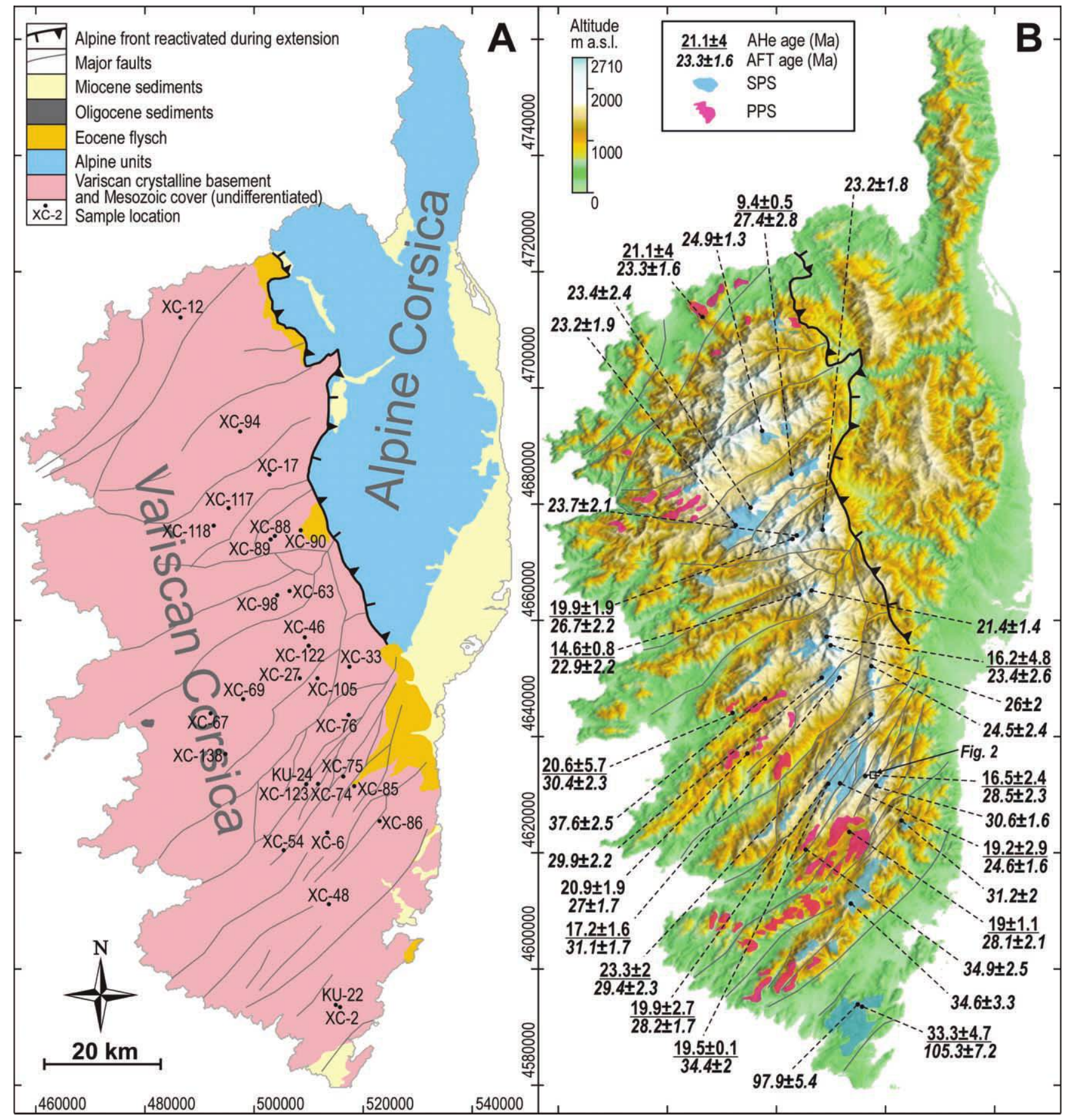

Figure 1. A, Geological sketch map of Corsica (after Rossi et al. 1980), with location of the samples from the planation surfaces. Coordinates are given in the UTM32/WGS84 system. B, Shaded digital elevation model of Corsica with position of summit planation surfaces (SPS; blue) and piedmont planation surfaces (PPS; red; modified after Kuhlemann et al. 2005); measured apatite (U-Th)/He (AHe) and apatite fission track (AFT) ages $\pm 1 \sigma$ errors (in Ma; AHe ages are written in normal underlined font; AFT in italic). 
scattered Miocene sediments in several small extensional basins along the eastern margins of Variscan and Alpine Corsica.

In the Oligocene, the compressional tectonic regime changed to an extensional regime due to the retreat of the Apenninic subduction zone, and the orogenic wedge started to collapse (Réhault et al. 1984; Doglioni 1991; Gueguen et al. 1998). The major Alpine thrust planes were reactivated as top down to the east (in present-day coordinates) extensional ductile shear zones by this time, leading to the exhumation of buried Variscan units (Réhault et al. 1984; Jolivet et al. 1990, 1991, 1998; Fournier et al. 1991; Brunet et al. 2000). At 30 Ma, continental rifting in the present-day Gulf of Lion started, subsequently leading to the opening of the Ligurian-Provençal Basin and the separation of the Corsica-Sardinia block from the European mainland (Bellaiche et al. 1976; Cherchi and Montadert 1982; Sérrane 1999). During the Early Miocene ( 21-17 Ma), the Corsica-Sardinia block rotated counterclockwise, close to its present position /Vigliotti et al. 1990; Vigliotti and Langenheim 1995; Gattacceca et al. 2007). As subduction rollback continued, the Tyrrhenian Basin opened between the Corsica-Sardinia block and the Apennines. This process left the Corsica-Sardinia block as a lithospheric boudin, flanked by two back-arc basins with respect to the westward-dipping Apenninic subduction zone (Doglioni et al. 1999).

\section{Geomorphological Setting}

Geomorphologic characteristics of the Alpine and Variscan parts of Corsica are substantially different (fig. 1B). Alpine Corsica exhibits a fairly mountainous topography. Maximum and mean elevation (1767 and $<1000 \mathrm{~m}$ asl, respectively), peak heights and topographic relief are lower than in the Variscan part. Variscan Corsica is dominated by mountainous, rugged topography where the most striking morphological features are southwest-northeasttrending ridges deeply incised by fault-controlled linear gorges and valleys. Maximum and mean elevation, peak heights, and topographic relief increase from the south-southeast to the north-northwest and reach their maximum in the Monte Cinto massif (mean elevation $>1400 \mathrm{~m}$ ).

Kuhlemann et al. (2005) mapped the island's lowrelief surfaces (as defined earlier by Rondeau 1961) in detail with a combination of field observations, satellite image analysis, aerial photographs, topographic maps, and a digital elevation model (DEM). The DEM analysis was based on mapping different geomorphometric parameters, such as average slope angles and standard deviation of local slope distribution, using a gliding window to identify low-angle areas bordered by abrupt breaks in slope, representing low-relief planation surfaces. They found the low-relief surfaces occur exclusively on Variscan basement and that their extent ranges from hundreds of square meters to tens of square kilometers. No elevated low-relief surfaces were found in the Alpine units. The largest low-relief surfaces are situated in the south whereas toward the north their extent diminishes with increasing elevation (fig. 1B). Kuhlemann et al. (2005) distinguished two types of low-relief surfaces: (i) summit surfaces (here named "summit planation surfaces" [SPSs]), plateaus atop the ridges at the level of local summits, at altitudes from $\sim 300$ to $\sim 2300 \mathrm{~m}$ asl, tilted in various directions around angles of $8^{\circ}-40^{\circ}$; and (ii) piedmont paleosurfaces (here named "piedmont planation surfaces" [PPSs]), referring to the low-relief regions in piedmont position, preserved at lower altitudes from $\sim 250$ to $\sim 900 \mathrm{~m}$ asl, uniformly dipping toward the southwest in the range of $10^{\circ}-20^{\circ}$.

The planation surfaces (fig. 2) are remarkably flat, cut across the Variscan crystalline basement, and are interpreted as uplifted remnants of erosion surfaces, planed to the former base level, possibly corresponding to a sea level (Rondeau 1961; Kuhlemann et al. 2005). Since the SPSs top the ridges and thus occupy the highest structural position in the Variscan basement, Kuhlemann et al. (2005) considered them to be remnants of a coherent erosion surface (or paleosurface) that was uplifted, offset by reactivated faults, tilted, and incised. According to these authors, the erosion surface formed during late Oligocene to Early Miocene times after a Late Eocene-mid-Oligocene uplift pulse. The maximum age was inferred from AFT data from the basement rocks, which revealed a distinct cooling period that the authors attributed to the erosional episode responsible for planation surface formation. The minimum age was inferred from deposition of upward-coarsening conglomerates of Burdigalian age (Orszag-Sperber and Pilot 1976), recording an uplift event at $\sim 17 \mathrm{Ma}$, which resulted in tilting and incision of SPSs. After this uplift event, the PPS is postulated to have formed in the piedmont position close to an existing base level. Its development was terminated at $\sim 11 \mathrm{Ma}$ by another uplift event, as inferred from the cessation of sedimentation in the intramontane basin of Francardo and the first occurrences of detrital material from the Alpine Corsica in coastal basins (OrszagSperber and Pilot 1976; Durand-Delga 1978; Ferrandini and Loÿe-Pilot 1992; Cubells et al. 1994). 


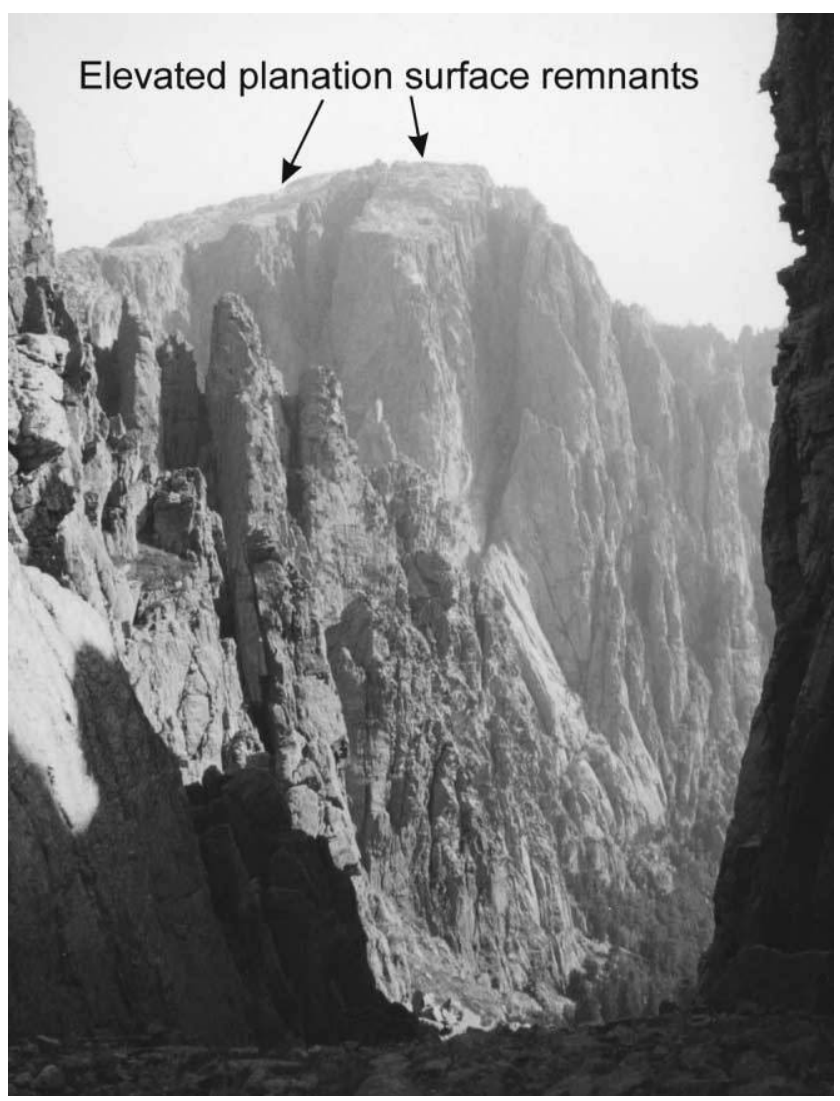

Figure 2. Photo of the uplifted summit planation surface at elevation of $\sim 1900 \mathrm{~m}$ asl from southern Corsica (photo courtesy of J. Kuhlemann; modified after Kuhlemann et al. 2005). Photo location on figure $1 B$.

Given the nature of these Corsican low-relief surfaces, we assume that the SPS represents remnants of a single low-relief erosion surface. This erosion surface was initially continuous and formed close to base level, corresponding to sea level at the time of their formation. This assumption is supported by the gently undulating, low-relief character of the plateaus, consistency of position atop the basement and the paleo-meander on one of the planation surfaces (Kuhlemann et al. 2005).

\section{Previous Thermochronological Studies}

A great deal of AFT and ZFT data have been reported from Corsica (Carpéna et al. 1979; Lucazeau and Mailhé 1986; Mailhé et al. 1986; Jakni et al. 2000; Cavazza et al. 2001; Zarki-Jakni et al. 2004; Fellin et al. 2005a, 2006; Danišík et al. 2007). More recently, zircon and apatite $(\mathrm{U}-\mathrm{Th}) / \mathrm{He}$ data from Alpine Corsica were reported (Fellin et al. 2005b). The results can be summarized as follows: Most of the Variscan crystalline basement is characterized by Late Jurassic to Early Cretaceous ZFT ages, and an Alpine rejuvenation of the ZFT system is lack- ing. The ages are interpreted as the result of a longlived thermal event related to high heat flow from mantle upwelling during rifting and subsequent opening of the Ligurian-Piedmont Ocean (Fellin et al. 2006; Danišík et al. 2007). In contrast, the basement along the Alpine deformation front is characterized by Cretaceous to Paleocene apparent ZFT ages resulting from partial resetting during Alpine nappe stacking (Fellin et al. 2006; Danišík et al. 2007). AFT data show that Variscan Corsica experienced cooling below $\sim 100^{\circ} \mathrm{C}$ during the Early Oligocene to Middle Miocene. This cooling is interpreted to have been related to erosional and tectonic denudation of the basement from below the Alpine nappes and foreland sediments (Cavazza et al. 2001; Danišík et al. 2007).

In contrast to Variscan Corsica, Alpine Corsica experienced widespread deformation and metamorphism during the Late Cretaceous and Eocene (Lahondère and Guerrot 1997; Brunet et al. 2000), reaching temperatures sufficient to partially or fully reset the ZFT system (Fellin et al. 2006) and fully reset the Ar-Ar system in mica (Brunet et al. 2000). AFT and (U-Th)/He data record rapid cooling 
during the Early to Middle Miocene, related to the exhumation of Alpine units as triggered by extensional tectonics (Fellin et al. 2005a, 2005b).

\section{Fission Track and (U-Th)/He Methodology}

Fission tracks produced by spontaneous fission of ${ }^{238} \mathrm{U}$ in U-bearing minerals such as apatite or zircon shorten (anneal) in response to temperature and time and thereby act as a time-recording thermometer. Shortening occurs at decreased rates (at geological timescales) in the partial annealing zone (PAZ), $110^{\circ}-140^{\circ} \mathrm{C}$ to $50^{\circ}-70^{\circ} \mathrm{C}$ for apatite and from $300^{\circ}$ to $400^{\circ} \mathrm{C}$ to $180^{\circ}-200^{\circ} \mathrm{C}$ for zircon /Gleadow et al. 1983, 1986; Green et al. 1989; Wagner and Van den haute 1992; Yamada et al. 1995a, 1995b; Brandon et al. 1998; Brix et al. 2002; Rahn et al. 2004; Tagami 2005). The analytical procedure used to generate fission track data is described in Danišík et al. (2007). We used the external detector method (Gleadow 1981) with the etching protocols of Donelick et al. (1999; 5.5 $\mathrm{M} \mathrm{HNO}_{3}$ solution for $20 \mathrm{~s}$ at $21^{\circ} \mathrm{C}$. We adopted Hurford and Green's (1983) zeta calibration approach to determine the age. The annealing properties of apatite grains were assessed by measurement of Dpar values (mean etch pit diameter of fission tracks on prismatic surfaces of apatite; Burtner et al. 1994).

$(\mathrm{U}-\mathrm{Th}) / \mathrm{He}$ thermochronology is based on retention and diffusive loss of ${ }^{4} \mathrm{He}$. The most important factors controlling this retention and diffusive loss are crystal size, time and temperature, distribution of parent isotopes, and radiation damage in the crystal lattice (Zeitler et al. 1987; Stockli et al. 2000; Farley 2002; Meesters and Dunai 2002a, 2002b; Shuster et al. 2006; Herman et al. 2007; Flowers 2009; Flowers et al. 2007, 2009). The ${ }^{4} \mathrm{He}$ is partially retained in the helium partial retention zone (HePRZ), where the temperature is estimated to be between $\sim 40^{\circ}$ and $85^{\circ} \mathrm{C}$ for apatite (Wolf et al. 1998), corresponding to a shallower depth interval in the Earth's crust than the analogous apatite PAZ (APAZ).

A detailed description of the analytical procedure of (U-Th)/He thermochronology analysis can be found in the appendix, available in the online edition or from the Journal of Geology office. In brief, apatite crystals were handpicked following strict selection criteria (Farley 2002) and their physical dimensions were measured. The crystals were then loaded in Pt tubes, degassed at $\sim 960^{\circ} \mathrm{C}$ under vacuum using furnace heating, purified and spiked with ${ }^{3} \mathrm{He}$, and analyzed for ${ }^{4} \mathrm{He}$ by a quadrupole mass spectrometer (Pfeiffer Prisma QMS-200). Degassed crystals were dissolved in nitric acid and analyzed by isotope dilution inductively coupled mass spectrometry using a VG PlasmaQuad 2 ICPMS. Total analytical uncertainty (TAU) was computed as a square root of sum of squares of weighted uncertainties on $\mathrm{U}, \mathrm{Th}$, and He measurements. TAU was used to calculate the error of raw AHe ages. The raw AHe were corrected for alpha ejection (Ft correction) after Farley et al. (1996). A value of $5 \%$ was adopted as the uncertainty on the Ft correction and was used to calculate errors for the corrected AHe ages.

The low-temperature thermal history based on AHe and AFT data was modeled using the HeFTy modeling program (Ketcham 2005), which combines both the fission track annealing and He production-diffusion models to reveal the potential thermal evolution pathways. The model was constrained by AHe data as follows: physical dimensions of analyzed prismatic and cylindrical grains were recalculated to spheres with equivalent surface-to-volume ratio, sphere radii were used to define the dimension of the modeled diffusion domain as recommended by Meesters and Dunai $(2002 a, 2002 b)$, diffusion parameters of Durango apatite from Farley (2000) were used, and homogeneous distribution of $U$ and $T h$ was assumed as inferred from the fission track distribution. We performed an inverse modeling procedure in unconstrained search style employing a Monte Carlo searching algorithm with a minimum of 500,000 paths tried. Further details of the modeling procedure can be found in the appendix text, figure, and tables.

\section{Results}

We present 15 new AHe results paired with published AFT data (Danišík et al. 2007) from samples from planation surface remnants at altitudes between $\sim 200$ and $\sim 2600 \mathrm{~m}$. Most of the samples were derived from Variscan granitoids; two samples were sandstones from the Eocene flysch cover. Fourteen out of 29 samples analyzed by the AFT method were not suitable for $(\mathrm{U}-\mathrm{Th}) / \mathrm{He}$ dating owing to the imperfect quality of the apatite crystals. These crystals were either too small (hindering valid application of alpha ejection correction; Farley et al. 1996), contained fluid inclusions (potentially trapping extraneous $\mathrm{He}$ ) or contained high uranium mineral inclusions such as zircon (that could not be fully degassed using the available furnace and cannot be dissolved using nitric acid). Initial attempts to date the imperfect crystals yielded anomalously old ages on the order of billions of years, disqualifying them from further efforts. 
AFT Data (Danišík et al. 2007). All but two samples yielded Cenozoic cooling AFT ages, ranging between $21.4 \pm 1.4$ and $37.6 \pm 2.5 \mathrm{Ma}$ (table A1; fig. $1 B$ ). Track length distributions of samples with Cenozoic ages were unimodal, negatively skewed, and relatively narrow, with mean confined track lengths (MTLs) between 13.2 and $14.8 \mu \mathrm{m}$ and standard deviations between 0.9 and $1.5 \mu \mathrm{m}$ (table $\mathrm{Al}$; fig. 3). The samples revealed fairly similar timetemperature $(t-T)$ paths characterized by moderate to fast cooling through the APAZ followed by isothermal holding at temperatures below the APAZ (Danišík et al. 2007). In contrast, two samples from the southernmost planation surface remnant (XC2, KU-22) yielded Cretaceous apparent AFT ages $(105.3 \pm 7.2$ and $97.9 \pm 5.4 \mathrm{Ma})$, with broad, bimodal track length distribution with a short MTL $(12.2 \mu \mathrm{m})$, attesting to reheating to temperatures within the APAZ (see details in Danišík et al. 2007 and the appendix).

(U-Th)/He Data. Results of the (U-Th)/He analyses are summarized in table $\mathrm{A} 2$ and shown in figure $1 B$. The AHe ages ranged from $38.2 \pm 3.1$ to $9.1 \pm 0.5 \mathrm{Ma}$; however, the vast majority cluster between 25 and $15 \mathrm{Ma}$. The oldest AHe ages were from the southernmost planation surface remnant. All AHe ages reproduced well and, with one exception, were all consistently younger than the corresponding AFT ages. Sample XC-12 yielded AHe ages that overlap with the AFT age within $1 \sigma$ error, indicating rapid cooling through the APAZ and HePRZ. The rest of the AHe ages may either indicate Oligocene to Miocene cooling or a more complex thermal evolution with a prolonged phase in the HePRZ. In order to resolve this question, thermal modeling is required.

Thermal Modeling Results. AHe results were used to refine the thermal modeling results of Danišík et al. (2007), based on AFT data (track lengths, single crystal fission track ages, and Dpar data) and calculated by the multikinetic annealing model of Ketcham et al. (2007). Only samples with available track length data were modeled. The modeling was constrained by AHe data as described in "Fission Track and (U-Th)/He Methodology." As in the case of AFT modeling (Danišík et al. 2007), known geological information and available ZFT data were converted into $t-T$ constraints: the beginning of the $t-T$ path was defined according to ZFT age domains proposed by Danišík et al. (2007); the end of the $t$ $T$ path was set to $13^{\circ} \mathrm{C}$ according to present-day mean surface temperature. As there are no geological indices pointing to a post-Eocene reheating of the basement, simple monotonic cooling scenarios were initially tested for each sample. In a second

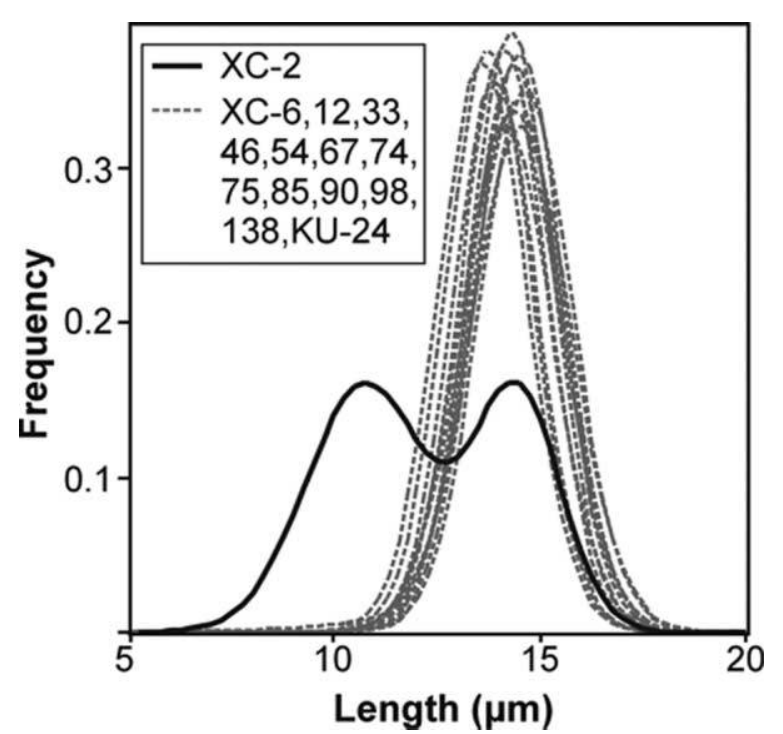

Figure 3. Confined track length distributions of the samples from the planation surfaces (for the original binned histograms of track length data see fig. 5 in Danišík et al. 2007 or fig. A1, available online or from the Journal of Geology office). Solid line = sample XC-2; dashed lines $=$ the rest (see text for explanation).

approach, episodic reheating scenarios were tested for each sample. With the exception of sample XC2 , however, these resulted in statistically less robust results characterized by low goodness-of-fit values (Ketcham 2005).

The statistically best thermal modeling results are presented in figure 4 . Modeled $t-T$ paths can be divided into three groups based on the similarity of trajectories modeled by combined AHe and AFT data and by AFT data alone (Danišík et al. 2007):

i) The first group is represented by samples XC2, XC-12, and XC-138. Their $t-T$ paths calculated by combined AFT and AHe data are very similar to those modeled by the AFT data alone but with narrower modeled $t$ - $T$ envelopes. Therefore, for this group, parameterization of the model by $\mathrm{AHe}$ data led to refinement of the results. Samples XC-12 and $\mathrm{XC}-138$ experienced rapid cooling through the APAZ and HePRZ followed by a period of modest cooling or isothermal holding at near-surface conditions lasting until the present. Sample XC-2, with an AFT-AHe age difference of $\sim 70 \mathrm{Ma}$, reveals a $t$ $T$ path with cooling through the APAZ from the Middle Jurassic to the Early Cretaceous, stagnation below the APAZ until the Early Paleocene, then reheating to levels within the APAZ at $\sim 45 \mathrm{Ma}$ (Eocene) that partially reset AFT ages and fully reset AHe ages. This was followed by a final fast cooling to surface temperatures in the Oligocene (for 

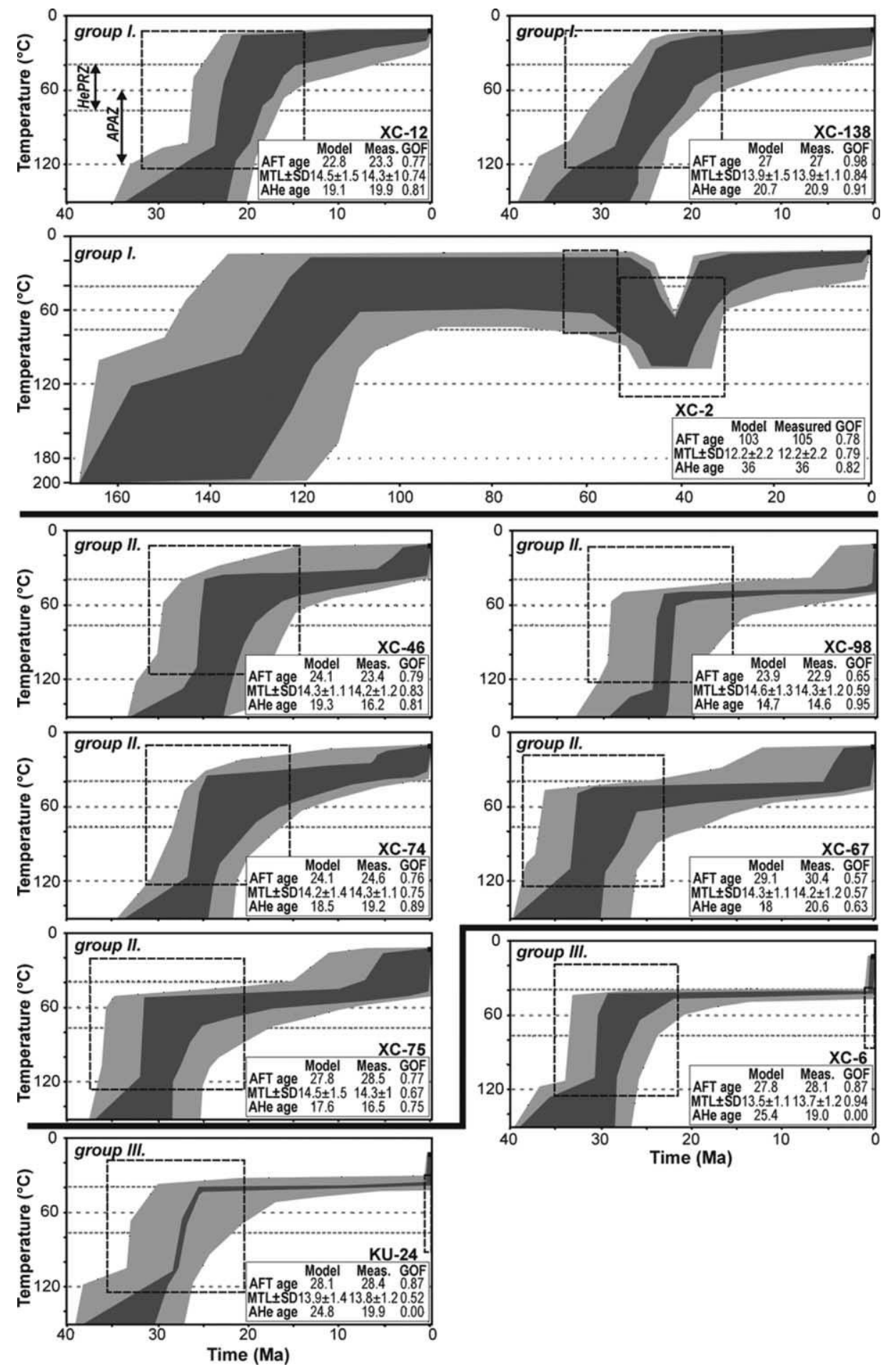

Figure 4. Thermal modeling results of apatite (U-Th)/He (AHe) and apatite fission track (AFT) data displayed in time-temperature diagrams modeled with the HeFTy program (Ketcham 2005). Light gray envelopes indicate acceptable fit; dark gray envelopes indicate good fit; dashed rectangles represent $t$ - $T$ constraints; APAZ = apatite partialannealing zone; HePRZ = apatite helium partial retention zone; MTL = mean track length $(\mu \mathrm{m}) ; \mathrm{SD}=$ standard deviation $(\mu \mathrm{m})$; GOF is goodness of fit (statistical comparison of the measured input data and modeled output data, where a "good" result corresponds to value 0.5 or higher). For explanation of groups I, II, and III, see the text. Note that in group III, the model was not constrained by AHe data but was forced to calculate the youngest AHe ages approved by AFT data. The modeled AHe ages are older than measured AHe ages. 
details see Danišík et al. 2007). In these samples, the AHe ages can be interpreted as cooling ages.

ii) The second group is represented by samples XC-46, XC-67, XC-74, XC-75, and XC-98. Their thermal histories show previously unrecognized features. Immediately after rapid cooling through the APAZ given by narrow unimodal track length distributions with long MTLs, the samples were held at nearly constant temperature within the HePRZ and below the APAZ temperature range until the onset of final cooling, which started at $\sim 6$ $\mathrm{Ma}$ or later. In these cases, the AHe ages result from prolonged residence at temperatures within the HePRZ and can be interpreted as apparent ages rather than cooling ages.

iii) The third group is represented by samples XC6 and KU-24, for which no $t-T$ path (neither good nor acceptable "fit") would reconcile requirements defined by the measured AHe and AFT data. In order to identify the difference between measured $\mathrm{AHe}$ ages and AHe ages that would be in accord with AFT data, we used forward modeling to find the $t-T$ paths that could fit the AFT data (i.e., reproduce measured AFT age and track length distribution) and simultaneously generate the youngest $\mathrm{AHe}$ age for a given sample. For sample XC-6, the youngest acceptable AHe age reconciling the AFT data is $\sim 26 \mathrm{Ma}$, whereas the measured $\mathrm{AHe}$ age is $19 \pm 1.1 \mathrm{Ma}$ (four aliquots: $18.0 \pm 0.9$, $18.3 \pm 1.0,19.2 \pm 1.0$, and $20.5 \pm 1.1 \mathrm{Ma})$. Similarly, for sample KU-24, the model approved AHe age is $25 \mathrm{Ma}$, whereas the measured age is $19.9 \pm 2.7 \mathrm{Ma}$ (five aliquots: $16.6 \pm 0.9,18.2 \pm$ $1.0,19.5 \pm 1.1,21.8 \pm 1.1,23.2 \pm 1.2 \mathrm{Ma})$.

\section{Interpretation and Discussion}

An age for planation can be determined from thermal trajectories by bracketing the episode of slow cooling or isothermal holding (Gunnell 2000). This should correspond to the stage when base levels have stabilized, the denudational system has reached a state of sufficiently low energy and planation has been occurring at the surface. In clearcut cases, the isothermal holding episodes are delimited by fast cooling episodes, corresponding to tectonic events and formation of a new base level (Gunnell 2000).

Thermal modeling results of all but one sample revealed a distinct fast cooling through the APAZ during the Oligocene to Early Miocene, followed by moderate cooling or isothermal holding, which either lasted until the present or was terminated by final cooling starting at $\sim 6 \mathrm{Ma}$ or later (fig. 4). Thus, a conventional and straightforward interpre- tation, based solely on the thermal modeling results, would suggest that the Oligocene-Early Miocene fast cooling episode may correspond to denudation of the basement and decay of topographic relief, resulting in formation of a planation surface. The subsequent isothermal holding episode represents the period of morphotectonic quiescence with low erosion rates. The age of the planation surface is thus bracketed by the breakpoints in the modeled cooling paths between $~ 30-20$ and 6-0 Ma. This scenario was proposed by Kuhlemann et al. (2005), who further suggested that the original planation surface (future SPS) formed postOligocene/Miocene and was uplifted at $\sim 17 \mathrm{Ma}$. Another erosion surface (future PPS) developed between 17 and $11 \mathrm{Ma}$ and was then uplifted from base level. Although this interpretation seems plausible, we suggest an alternate interpretation, based on the new thermochronological data and field observations.

Geological Evidence. In the field we found two sites where sparse occurrences of Eocene flysch sediments were preserved on the top of SPS remnants. The sediments were not truncated by the erosion surface but overlapped it, providing solid evidence for a minimum age of the SPS. Moreover, AFT ages of flysch samples from these two localities (samples XC-85 and XC-90; see fig. $1 \mathrm{~A}$ ) as well as AFT ages of the other eight flysch samples from the border zone between Alpine and Variscan Corsica (see details in Cavazza et al. 2001; Danišík et al. 2007) were all younger than the depositional age. This suggests the existence of extensive flysch cover, which buried the existing planation surface to significant depth during Alpine collision and was later removed. The SPS is thus a re-exposed surface of pre-Eocene age.

As argued by Danišík et al. (2007), during the Alpine collision, Variscan Corsica subsided and was buried below an eastward-thickening wedge of flysch, with the eastern part being overridden by the Alpine nappes. The minimum thickness of overburden as deduced from AFT thermal modeling was $\sim 4-8 \mathrm{~km}$ (assuming a thermal gradient of $20^{\circ}-$ $10^{\circ} \mathrm{C} / \mathrm{km}$; Danišík et al. 2007).

Thermal Modeling Results-A Critical Evaluation. Even though HeFTy modeling found cooling paths reconciling both AFT and AHe data for the majority of samples, the modeled cooling paths really represent only a kind of mathematical construct that matched the measured data, successfully passed some statistical tests, and is heavily dependent on modeler's constraints and other input parameters (Ketcham 2005). The question is whether these statistically acceptable cooling paths are also geolog- 
ically meaningful. We suspect that the cooling paths modeled for some of the samples (i.e., group II in "Thermal Modeling Results") do not approximate the real thermal evolution of the samples and thus present no supporting evidence for inferred planation at that time.

The derived cooling paths are characterized by a long period of isothermal holding at levels "contouring" the upper limit of the APAZ and terminated by sudden final cooling at $\sim 6 \mathrm{Ma}$ or later (fig. 4). Such a cooling path is, however, not in agreement with independent geological observation; there are numerous occurrences of terrestrial sediments derived from the Variscan basement in the Late Oligocene to Miocene period (i.e., of Chattian, Burdigalian, and Tortonian age; Orszag-Sperber and Pilot 1976; Ferrandini and Loÿe-Pilot 1992; Ferrandini et al. 1998, 1999), indicating that the basement was being eroded and rocks exhumed at that time. Isothermal holding of rocks during exhumation can be explained by advection of isotherms, which would hold the Corsican samples, despite being moved toward the surface, at constant temperatures over most of the Late Oligocene-Late Miocene period. This could only be accomplished by a geothermal gradient that increased immediately after each exhumation pulse and thus is not realistic, as the geothermal gradient in Corsica most likely reached its maximum during Early Miocene rifting and then decreased. It is possible that Neogene erosion on planation surfaces was not deep enough to affect the AHe and AFT systems. Nonetheless, it is highly unlikely that, during most of the Neogene, the samples were held at almost constant temperatures despite vigorous tectonic activity.

Furthermore, final cooling between $6 \mathrm{Ma}$ and the present, which suggests an additional phase of erosion in the Pliocene-Pleistocene and might be interpreted as being related to the creation of the modern topography, conflicts with the conclusions of Kuhlemann et al. (2005). Inferring from the shallow-marine Early Pliocene sediments found in several locations along the west and southwest coast at elevations of $<200 \mathrm{~m}$ asl, the authors argued that, despite glacial modification in the Pleistocene, the landscape of Corsica acquired much of its present shape before the Pliocene.

We suspect the "fast cooling-plateau-fast cooling" pattern of the modeled cooling paths (best represented by samples XC-6, XC-98, and $\mathrm{KU}-24$ ), is an artifact created by the modeling algorithm which certainly reconciles measured data but is not representative of the true geological evolution. A strikingly similar cooling pattern was reported in several other studies combining AFT and AHe data (e.g., Spiegel et al. 2007). We suspect that this might be a result of a discrepancy in cross-calibration of thermal sensitivity for the AFT and AHe systems, where either fission track annealing and/or He diffusion kinetics in apatite are not yet fully understood, and/or simply a result of imperfection in the HeFTy modeling program.

Inconsistencies between AFT and AHe data have been recognized in several studies of old ( $>100 \mathrm{Ma}$ ) cooling histories (e.g., Belton et al. 2004; Hendriks and Redfield 2005; Green and Duddy 2006; Green et al. 2006; Danišík et al. 2010; Flowers and Kelley 2011) where AHe ages were often older than predicted from the thermal histories resulting from modeling AFT data. Several studies attributed this result to radiation damage in the crystal lattice structure of apatite, which increased the retentivity of $\mathrm{He}$, resulting in anomalously high $\mathrm{AHe}$ ages (Green et al. 2006; Shuster et al. 2006; Flowers et al. 2007, 2009; Flowers 2009). We do not think this applies to our AHe ages for the following reasons: (i) we do not see any correlation between AHe age and effective uranium concentration (table A2) which would be expected if radiation damage played a large role (Shuster et al. 2006; Flowers et al. 2009); (ii) our AHe ages appear to be too young and not too old, as would be expected from apatite damaged by radiation (Green et al. 2006; Shuster et al. 2006); and (iii) our samples are likely too young (AFT typically $<40 \mathrm{Ma}$ ) and too low in uranium (typically $<60 \mathrm{ppm}$ ) to have been affected by radiation damage.

Further, Hansen and Reiners (2006) showed that, in spite of the consistency between AFT and AHe ages (i.e., AFT ages $>$ AHe ages), there is a mismatch in modeled thermal histories derived from AFT and AHe data. In short, the authors found that thermal histories required to reproduce measured AFT data predict AHe ages younger than measured and vice versa. Our results show an inverse relationship. Thermal paths derived from AFT data tend to predict AHe ages older than measured and, conversely, thermal paths derived from $\mathrm{AHe}$ data tend to predict AFT ages younger than measured. This problem is perhaps most pronounced in samples XC-6 and KU-24 (see fig. 4; "Thermal Modeling Results").

There are several potential explanations: analytical effects in (U-Th)/He and/or FT measurements, wildfires, and inconsistency between AFT and AHe systems. With respect to the precision and accuracy of $(\mathrm{U}-\mathrm{Th}) / \mathrm{He}$ ages, results on age standards reproduced acceptable values (mean AHe age of Durango [30 replicates]: $30.8 \pm 2.5 \mathrm{Ma}$; reference Durango AHe age: $31.1 \pm 1.0 \mathrm{Ma}$; McDowell et al. 2005). 
The samples in this study were not analyzed for Sm, and that might lead to an underestimate of the true AHe ages. However, all samples contain apatite with "average" U concentration (> 20 ppm U), so the contribution of ${ }^{147} \mathrm{Sm}$ to the final AHe age should be $<1 \%$ (Carter 2003; Hansen and Reiners 2006). There is also no obvious reason why the Ft correction might have been underestimated. All analyzed crystals were euhedral hexagonal prisms with almost identical width to length ratios (Farley et al. 1996; Farley 2002). In addition, all crystals selected for measurement were free of microscopically visible cracks that might cause He loss resulting in too young ages.

In terms of the AFT data, Ketcham et al. (2009) pointed out that reproducibility of track length measurements can vary among analysts. However, our results (unimodal track length distributions with long MTLs) are consistent with track length data reported by other studies in Corsica (ZarkiJakni et al. 2004; Fellin et al. 2005a). Shrub vegetation in Corsica is affected by annual wildfires that might cause He loss in the upper $30 \mathrm{~cm}$ of exposed bedrock (Mitchell and Reiners 2003) or rejuvenate AFT age (Reiners et al. 2007). However, this problem was circumvented during sampling by removing the upper section $(\sim 30-50 \mathrm{~cm})$ of rock before sampling.

The discrepancy, therefore, is most likely related to an inconsistency between the AFT and AHe systems when they are modeled together. Perhaps, the modeled cooling paths were biased by assigning diffusion characteristics (Durango apatite, after Farley 2000) that were not appropriate for these samples. Alternately, HeFTy may not be the ideal modeling software for handling various input data sets. We can conclude only that there may be a fundamental problem with cross-validation of AFT and AHe systems, not only in samples with long-term low-temperature cooling evolution (Hendriks and Redfield 2005; Green and Duddy 2006; Hansen and Reiners 2006) but also in samples with apparently simple, fast cooling histories. The important point to note is that thermal histories derived from combined AFT and AHe data yielding the "fast cooling-plateau-fast cooling" pattern should be interpreted with caution. Because the modeled result could simply represent a statistically valid mathematical solution, it should be always backed up by available geological evidence (as recommended by Ketcham 2005).

Duration of the Planation Period. As evidenced in the sedimentary record, Variscan Corsica experienced several uplift episodes ( 25-24, $\sim 17$, and 11-10 Mal associated with the growth of topo- graphic relief (Kuhlemann et al. 2005). This history conflicts with the morphotectonic quiescence required for the formation of a planation surface and the isothermal holding (possibly falsely) revealed by the thermal modeling. If the erosion surface formed between these uplift pulses, the time available for planation would be $<\sim 8 \mathrm{Ma}$. Whether this is long enough to create an erosion surface in the granitoid-dominated lithology of Variscan Corsica is debatable. To the authors' knowledge, the only reliable constraints demonstrated that in Neogene Greenland $\sim 20 \mathrm{~m}$.yr. was long enough and $\sim 5 \mathrm{~m}$.yr. was a too short a time to create a planation surface (Japsen et al. 2009). A similar figure (15-20 m.yr.) was reported from the Central Iberian Chain in Spain by Casas-Sainz and Cortés-Gracia (2002).

The planation process is controlled by several factors, the most important being lithology and climate, and unfortunately, the Greenland example is not an analogue to Corsica in terms of either. In Corsica, the planation surface was formed on granitoids that are physically and chemically resistant to erosion. The climate is characterized by subtropical Mediterranean-type conditions of dry and warm summers and temperate humid winters. In the Miocene, Corsican mean annual temperatures were slightly higher than today and erosional processes could have operated more rapidly; however, we speculate that the required erosion would not have occurred in $8 \mathrm{~m}$.yr.

Age of the Planation Surface Remnants. As mentioned in "Geological Evidence," the minimum age of the SPS is delimited by remnants of Eocene flysch sediments. The maximum SPS age can be derived from the southernmost SPS remnants, the only location in Corsica preserving Mesozoic AFT memory. Both samples from this plateau $\mathrm{XC}-2$ and KU-22) yielded by far the oldest AFT and AHe ages $(\mathrm{AFT}, \quad 97.9 \pm 5.4$ and $105.3 \pm 7.2 \mathrm{Ma} ; \mathrm{AHe}$, $32.8 \pm 3.1 \mathrm{Ma})$. The modeled $t-T$ path suggests isothermal holding at temperatures below $\sim 60^{\circ} \mathrm{C}$ between the Early Cretaceous $(\sim 120 \mathrm{Ma})$ and Paleocene ( $60 \mathrm{Ma})$. A $\sim 120-\mathrm{Ma}$ maximum SPS age is supported by abundant coarse-grained detrital material derived from the Variscan basement in Cretaceous sequences of Alpine nappes (Rossi et al. 1980), indicating exposure and erosion of the basement at that time. The SPS is thus bracketed between $\sim 120$ and $\sim 60 \mathrm{Ma}$.

Unlike the SPS, it is not possible to constrain the age of the PPS due to the lack of geological constraints and invariability of thermochronological data. We examined the relationship between SPS and PPS by plotting the AFT and AHe ages as a function of elevation. In this plot one would expect 


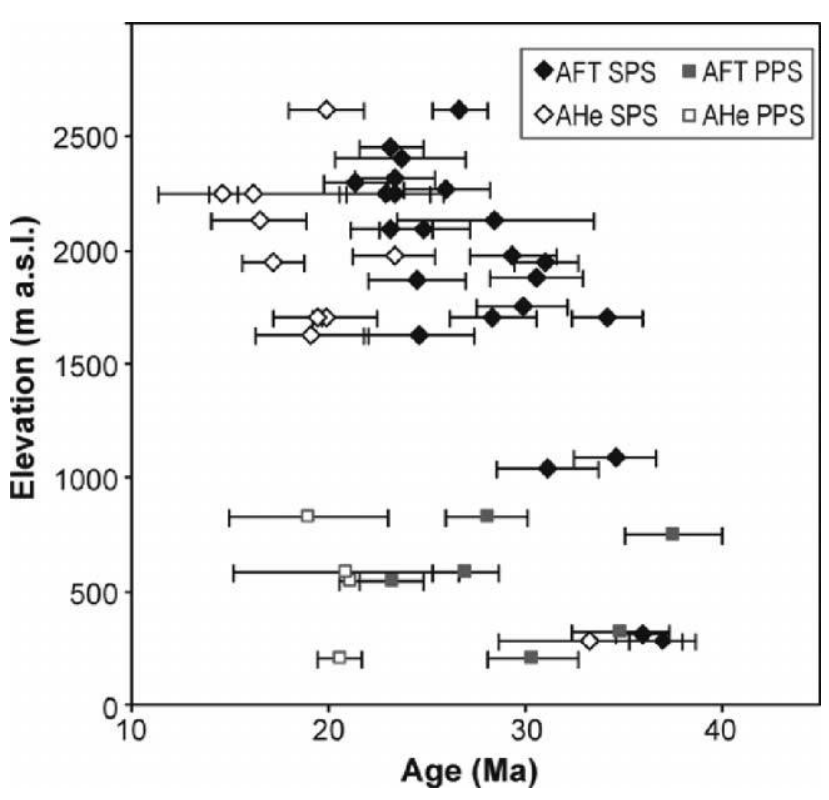

Figure 5. Age-elevation plot of the summit planation surfaces (SPS) and piedmont planation surfaces (PPS) samples as classified by Kuhlemann et al. (2005). Cooling age of the samples XC-2 and KU-22, which yielded Cretaceous apparent apatite fission track (AFT) ages, was estimated from the modeled $t-T$ path. $A H e=$ apatite $(\mathrm{U}-$ Th)/He.

a positive correlation, as the higher-altitude SPS are thought to be older and should yield older ages. However, as shown by the age-elevation plot (fig. $5)$, all the data form a cluster of Early to early Middle Miocene ages, and there is no difference in age between the SPS and PPS. This means that all samples were cooling through the APAZ and HePRZ at the same time and the vertical differentiation of two surface generations must have happened later.

We propose that the PPS could have developed during post-early Early Miocene times. This interpretation may find support in relative position of the PPS against the SPS, and in the AFT and AHe ages cooling ages that should predate the PPS. Second, and perhaps more simply, we speculate that PPS remnants may represent the basement blocks topped by original SPS, which either experienced less uplift or were downthrown along normal faults. At present, they are preserved at piedmont position and are defined as PPS. This simple explanation is, however, not supported by the field observations of Kuhlemann et al. (2005) who argued that SPS and PPS remnants are separated by moderate slopes with irregular bending, which cannot be created by a system of normal faults and that the detachment faults separating SPS and PPS remnants are not always recognizable in the field.
Third, we hypothesize that PPS occupied the piedmont position before the Eocene collision, so the relative position of the SPS and the PPS perhaps was similar (but with smaller vertical differences) to that of the present. During Oligo-Miocene times, PPS was exhumed uniformly with SPS so the resulting thermochronological record from SPS and PPS is identical.

Lateral Propagation of Exhumation. Once the age of the planation surface is constrained, these prominent morphostratigraphic markers can be particularly useful in studies of topographical evolution in space. In order to reveal lateral trends in basement exhumation, the AFT and AHe ages were plotted versus distance from the latitude of the southern tip of Corsica (fig. 6). Both AFT and AHe ages show a clear trend toward younger ages from south to north proving that cooling through the APAZ and HePRZ was diachronous, taking place in the Oligocene in the south and in the Early Miocene in the north. This trend is corroborated by observation of the sediments: the first postcollisional terrestrial sediments derived from the basement were deposited in the Late Oligocene (25-24 $\mathrm{Ma}$ ) on the southwest coast (Ferrandini et al. 1999), while in the central and northern part of the island, the basement emerged in the Burdigalian ( 17 Ma; Orszag-Sperber and Pilot 1976; Ferrandini and Loÿe-Pilot 1992; Kuhlemann et al. 2005). The trend in the cooling pattern clearly correlates with topography: maximum and mean elevation, relief, and slope angles all increase gradually from south

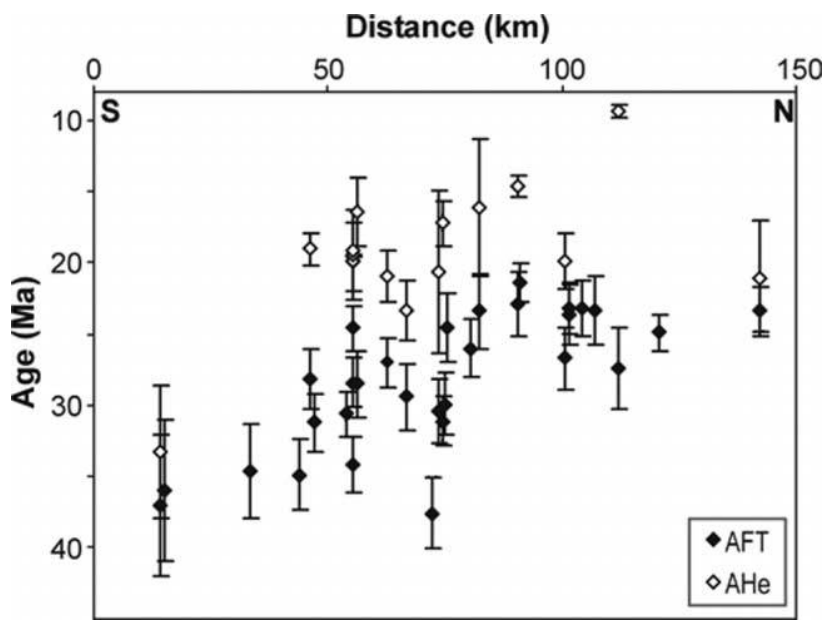

Figure 6. Apatite fission track (AFT) and apatite (U-Th)/ $\mathrm{He}(\mathrm{AHe})$ ages plotted as a function of distance from the southernmost margin of Corsica, where a trend of ages decreasing toward the north is visible. Cooling age of the samples XC-2 and KU-22, which yielded Cretaceous apparent AFT ages, was estimated from modeled $t-T$ path. 
to north. In the north, moreover, remnants of the planation surface are at higher altitudes, smaller in aerial extent, and less well preserved than in the south. We conclude that exhumation of the planation surface remnants and growth of topographic relief had begun in the south in the Late Oligocene and propagated toward the north through to the Early Miocene.

We consider this pattern to be the consequence of (i) thinning of the lithospheric mantle beneath the Corsica-Sardinia block during the course of rifting and (ii) differences in the thickness of the overlying sedimentary and tectonic stack, which the Variscan basement inherited during the Eocene collision and which diminished toward the south (Danišík et al. 2007). The first process is supported by the fact that mantle lithosphere underneath Corsica becomes thinner in a north-northwest direction (Cloetingh et al. 2005). The isostatic response of the crust, which is characterized by a thickness of $26-30 \mathrm{~km}$ all across the Corsica-Sardinia block (Cloetingh et al. 2007), thus results in greater uplift in the north than in the south. This explains the southward tilt of the entire island. The basement in the south was covered by only relatively thin flysch deposits and was, therefore, exhumed from shallower levels and passed through the APAZ by the Late Oligocene. The lower degree of exhumation led to a reduced isostatic response resulting in less surface uplift and lower topography with lower gradients. In contrast, the basement in the north was covered by a thicker pile of flysch and partly by the Alpine nappes and was exhumed from a greater depth and later than the basement in the south. Greater isostatic response resulted in greater surface uplift and higher topography with steep gradients. Accordingly, valley incision and widening was more intense and the planation surface was cut off more effectively in the north.

Summarizing Landscape Model. On the basis of the geological record, landform analysis, and fission track and AHe data, we present the following scenario of the landscape evolution of Corsica (figs. 7, 8). In the Middle to Late Jurassic ( 170-145 Ma), the Ligurian-Piedmont Ocean opened between the Gondwanan and Laurasian plates (the latter including the Corsican crystalline basement; Frisch 1979). Rifting and ocean opening was associated with increased heat flow related to mantle upwelling. The Variscan basement of Corsica was situated in the vicinity of the rift, as recorded by fully and partially reset ZFT ages (Fellin et al. 2006; Danišík et al. 2007).

The presently exposed basement level cooled through the APAZ and reached near-surface con- ditions in the Early Cretaceous $(\sim 120 \mathrm{Ma})$, as indicated by the breakpoint in the modeled thermal path. Cooling was attributed to the combined effect of (i) drift away of the basement from the heat source in the course of continuous ocean-floor spreading and (ii) exhumation of the basement by removal of Mesozoic cover strata. The basement was exposed to erosion, as inferred from the abundant occurrences of coarse-grained detrital material derived from the Variscan basement in Cretaceous sequences of some of the Alpine nappes (Rossi et al. 1980).

According to thermal modeling and the stratigraphic record, the basement could have been exposed and eroded in a period of tectonic quiescence between $\sim 120$ and $\sim 60 \mathrm{Ma}$ (Early Cretaceous to Paleocene). Under decreasing erosion conditions, the planation surface was created. In the Early Tertiary ( 60 Ma), the Variscan basement approached the Alpine subduction zone as a part of the lower plate. A wedge of flysch, thickening toward the trench, was deposited on the top of the planation surface. This process sealed the planation surface. The eastern part of the basement and the flysch wedge was subducted beneath the Alpine nappes. The major part of the basement reached maximum temperatures between APAZ and zircon PAZ (Danišík et al. 2007). An exception was the southernmost part, where the flysch overburden was thin and the AFT system was only partially reset at temperatures within the APAZ. Despite its significant burial over a large area, the planation surface was not destroyed due to its stability of a surface formed on mechanically and chemically resistant granites, and the protective function of the overlying soft sediments.

The Oligocene ( 35-23 Ma) was a period of tectonic reorganization in which several tectonic events occurred. At $\sim 33 \mathrm{Ma}$ the boundary conditions changed from compression to extension and the overthickened crust started to collapse (Jolivet et al. 1990; Brunet et al. 2000). At $\sim 30 \mathrm{Ma}$ a rift formed, separating the future Corsica-Sardinia microplate from the European mainland (Bellaiche et al. 1976; Cherchi and Montadert 1982; Sérrane 1999). Crustal extension was the consequence of eastward rollback of the newly formed, west-dipping Apennine subduction zone after slab break-off of the east-dipping Alpine subduction zone (Réhault et al. 1984; Doglioni 1991; Gueguen et al. 1998). In this setting, the Variscan basement started to exhume and a post-Eocene erosion surface was formed after removal of at least $4 \mathrm{~km}$ of overburden. The planation surface was cut by reactivated subvertical faults, defining differentially behaving blocks and the subsequent orientation of valleys. 


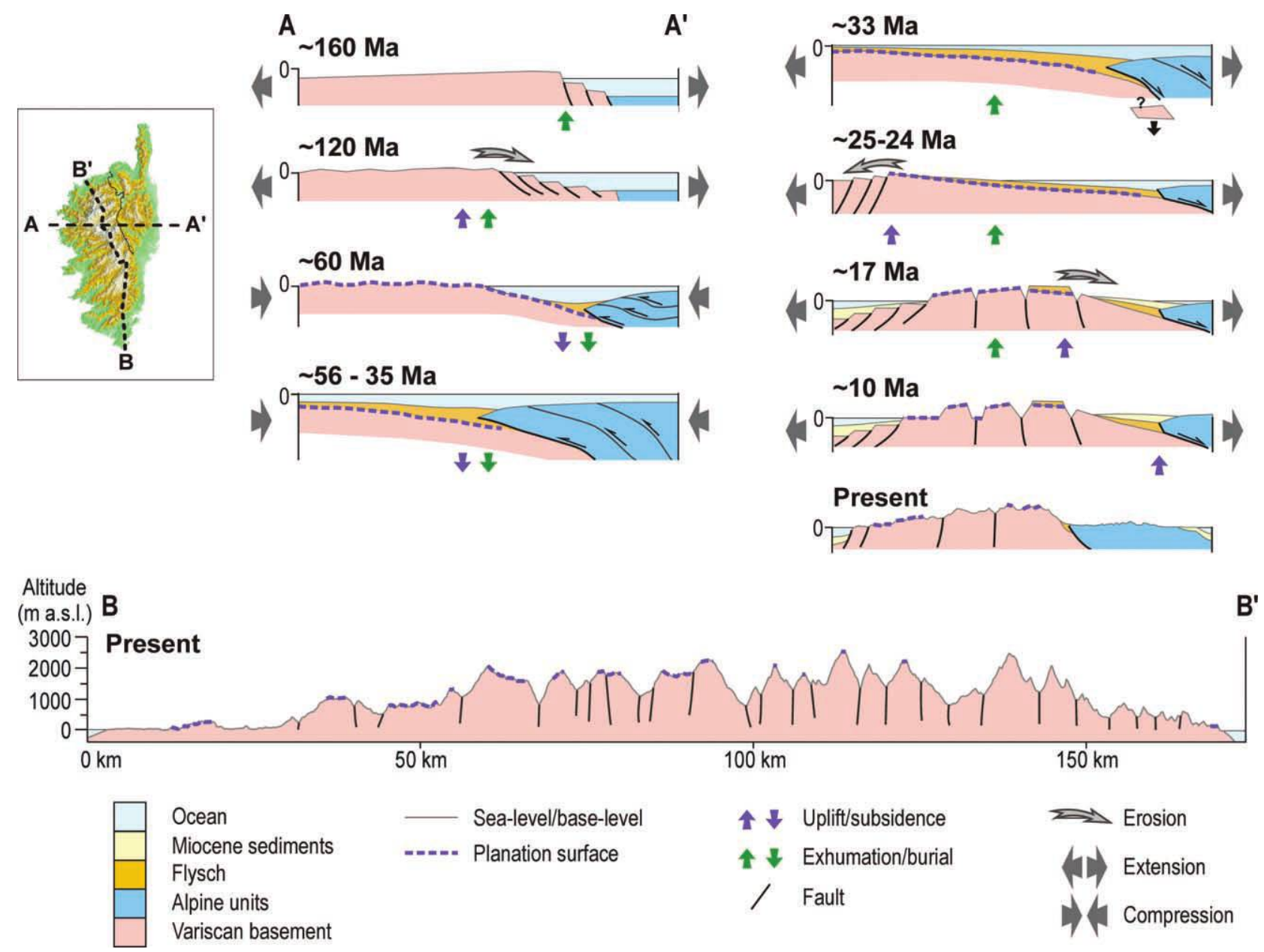

Figure 7. Simplified model of landscape evolution of Variscan Corsica in the geodynamic context depicted along a W-E (A-A') profile (in present-day coordinates). The bottom panel depicts the real present-day topography of the basement; the trace of the profile can be found top left. Refer to the text for full explanation.

Cooling of the individual blocks through the APAZ progressed diachronously from the south toward the north. Exhumation did not necessarily lead to the immediate development of topographic relief, because in the first stages the sedimentary cover of the planation surface could be easily eroded without considerable surface uplift and incision of deep valleys. Surface uplift increased and topographic relief started to grow but not before the latest Oligocene ( 25-24 Ma) when the resistant basement was finally reexposed, as indicated by continental conglomerates with granitic clasts on the southwest coast of the island.

In the early Miocene, the Corsica-Sardinia block rotated counterclockwise close to its present position (Vigliotti et al. 1990; Vigliotti and Langenheim 1995; Gattacceca et al. 2007). The basement blocks with the planation surface remnants were offset along the faults, uplifted and differentially tilted, which triggered fluvial valley incision and thus marked the onset of destruction of the reexposed planation surface. At $\sim 17 \mathrm{Ma}$, a large portion of crystalline basement acted as a source for material deposited in sedimentary basins in the east, indicating uplift and growth of topographic relief. During Middle to Late Miocene times, differential uplift and tilting of individual blocks, as well as valley incision and widening, continued at the expense of the planation surface remnants. At $\sim 11$ $\mathrm{Ma}$, Corsica was affected by another uplift phase, when the deposition in the Miocene basins along the basement terminated and the Alpine part emerged above the local base level.

\section{Conclusions}

The previous attempt to establish a geochronology of planation surfaces in Corsica based on AFT data 


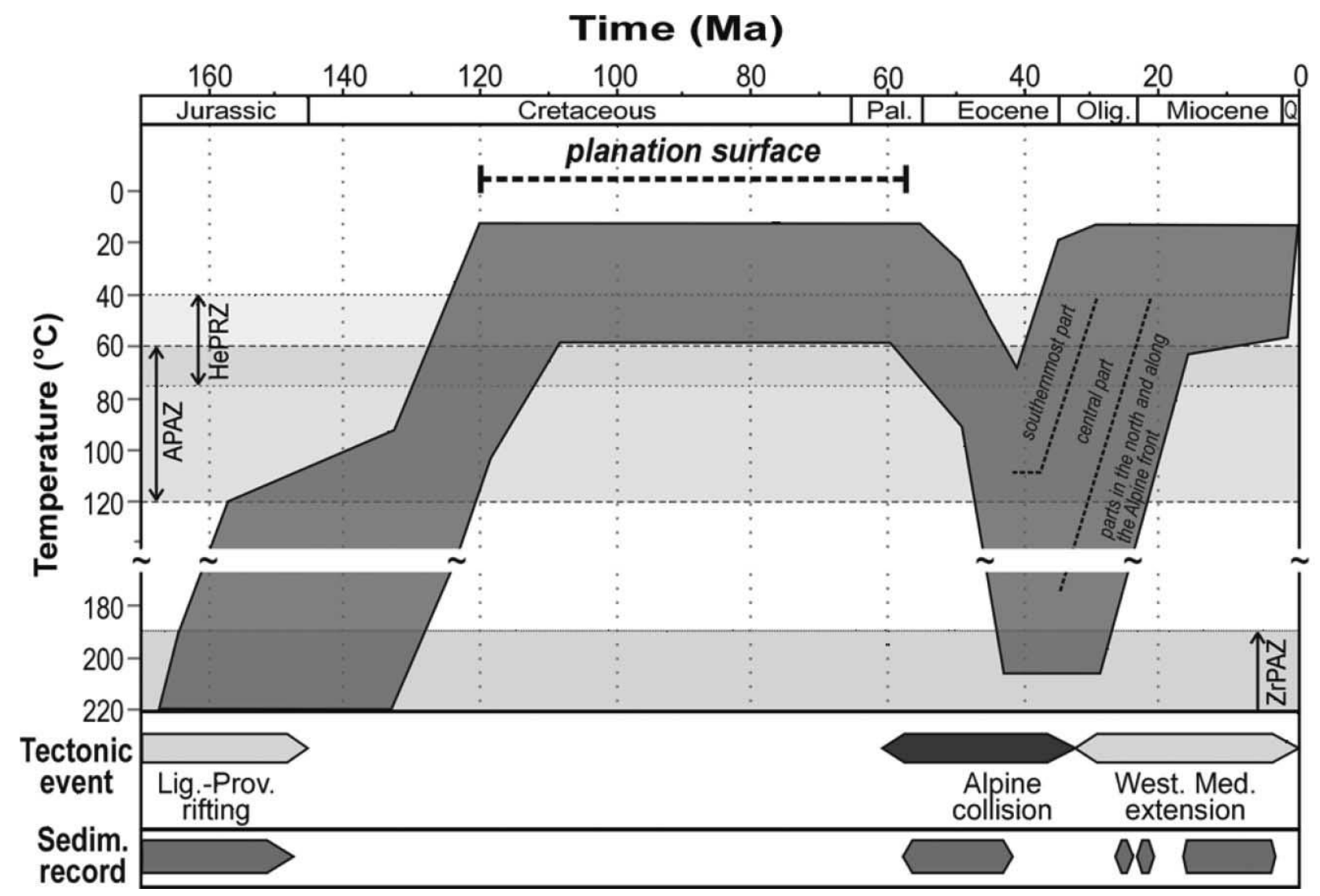

Figure 8. Summarizing time-temperature evolution of the Variscan crystalline basement of Corsica drawn from thermal modeling results of zircon fission track (ZFT), apatite fission track (AFT), and apatite (U-Th)/He (AHe) data, and regional geological considerations (see text for explanation). According to our new interpretation, the planation surface existed before the Eocene collision. ZrPAZ = zircon partial-annealing zone.

suggested that these surfaces formed after the Late Eocene-mid-Oligocene. Based on a combination of new and published low-temperature thermochronological data (ZFT, AFT, and AHe), landform analysis, and reexamination of the stratigraphic record, we propose an alternative scenario: the SPS in Corsica formed between $\sim 120$ and $\sim 60 \mathrm{Ma}$ and was then buried to depths of $>\sim 4 \mathrm{~km}$ during Eocene collision but not destroyed due to the protective function of a thick flysch cover. In the OligoceneMiocene it was exhumed and fault-segmented into blocks, which were differentially uplifted to elevations of (in places) $>2 \mathrm{~km}$, creating much of the present-day topography of Corsica. The SPS is thus a reexposed planation surface. This unique example shows that under favorable conditions ancient landforms, typical of tectonically stable areas, are able to survive in tectonically active settings such as collisional plate margins.

Our results indicate that, despite having great potential in low-temperature thermochronology when used in tandem, allowing refinement of thermal models and results, there might be inconsistencies between AFT and (U-Th)/He data when modeling thermal histories. In this study, combined modeling of AFT and (U-Th)/He data lead to apparent scenarios with isothermal holding at the levels below the APAZ followed by Late Neogene cooling, which conflict with independent geological constraints and therefore appear to be unrealistic. Thus, we suggest that there might be a discrepancy between the AFT and (U-Th)/He systems not only in the case of extremely old terrains but also in the case of rocks with a relatively simple, young cooling history. Therefore, attention should be paid to cross-calibration of both systems in the overlapping critical temperature range.

\section{A C K N O W LED G M EN T S}

This study was funded by the German Science Foundation (DFG). G. Höckh, D. Mühlbayer-Ren- 
ner, and D. Kost (Tübingen) are thanked for careful sample preparation. Colleagues at the Scottish Universities Environmental Research Centre in East Kilbride (UK) are thanked for conducting U-Th measurements. B. Székely received financial support from the University of Tübingen in the framework of Nachwuchswissen- schaftlerförderung. We thank P. van der Beek (Grenoble), P. Vermeesch (London), F. Herman (Zürich), G. Fellin (Zürich), P. Japsen (Copenhagen), P. Green (Melbourne), and D. Rowley (Chicago) for thorough reviews that improved the manuscript and considerably helped us in clarifying our ideas.

\section{R E F ER E N C ES C I T E D}

Babault, J.; Van Den Driessche, J.; Bonnet, S.; Castelltort, S.; and Crave, A. 2005. Origin of the highly elevated Pyrenean peneplain. Tectonics 24:TC2010, doi: 10.1029/2004TC001697.

Bellaiche, G.; Irr, F.; and Labarbarie, M. 1976. Découverte de sédiments marins fini oligocène-aquitanien au large du Massif des Maures (Canyon des Stoechades). C. R. Acad. Sci. Paris 283:319-322.

Belton, D. X.; Brown, R. W.; Kohn, B. P.; Fink, D.; and Farley, K. A. 2004. Quantitative resolution of the debate over antiquity of the central Australian landscape: implications for the tectonic and geomorphic stability of cratonic interiors. Earth Planet. Sci. Lett. 219:21-34.

Bézert, P.; and Caby, R. 1988. Sur l'âge post-bartonien des évènements tectono-métamorphiques alpins en bordure orientale de la Corse cristalline (nord de Corte). Bull. Soc. Geol. Fr. 6:965-971.

1989. La déformation progressive de l'éocène de la région de Corte: nouvelle donne és pé trostructurales et conséquences pour la tectogénèse alpine en Corse. C. R. Acad. Sci. Paris 309:95-101.

Bonow, J. M.; Lidmar-Bergström, K.; Japsen, P.; Chalmers, J. A.; and Green, P. F. 2007. Elevated erosion surfaces in southern Norway and West Greenland: their significance in studies of uplift and tectonic events. Norw. J. Geol. 87:181-196.

Brandon, M. T.; Roden-Tice, M. K.; and Garver, J. I. 1998. Late Cenozoic exhumation of the Cascadia accretionary wedge in the Olympic Mountains, NW Washington State. Geol. Soc. Am. Bull. 110:985-1009.

Brix, M. R.; Stockhert, B.; Seidel, E.; Theye, T.; Thomson, S. N.; and Kuster, M. 2002. Thermobarometric data from a fossil zircon partial annealing zone in high pressurelow temperature rocks of eastern and central Crete, Greece. Tectonophysics 349:309-326.

Brown, R.; Gallagher, K.; Gleadow, A. J. W.; and Summerfield, M.A. 2000. Morphotectonic evolution of the South Atlantic margins of Africa and South America. In Summerfield, M.A., ed. Geomorphology and global tectonics. Wiley, Chichester, p. 255-281.

Brunet, C.; Monié, P.; Jolivet, L.; and Cadet, J. P. 2000. Migration of compression and extension in the Tyrrhenian Sea, insights from ${ }^{40} \mathrm{Ar} /{ }^{39} \mathrm{Ar}$ ages on micas along a transect from Corsica to Tuscany. Tectonophysics 321:127-155.

Burtner, R. L.; Nigrini, A.; and Donelick, R. A. 1994. Thermochronology of Lower Cretaceous source rocks in the Idaho-Wyoming thrust belt. Am. Assoc. Petrol. Geol. Bull. 78:1613-1636.

Caron, J. M.; Kiénast, J. R.; and Triboulet, C. 1981. Highpressure/low-temperature metamorphism and polyphase alpine deformation at Sant'Andrea di cotone (eastern Corsica, France). Tectonophysics 78:419-451.

Carpéna, J.; Mailhé, D.; Naeser, C. W.; and Poupeau, G. 1979. Sur la datation par traces de fission d'une phase tectonique d'age Eocène supérieur en Corse. C. R. Acad. Sci. Paris 289:829-832.

Carter, T. J. 2003. Apatite (U-Th)/He thermochronometry of metamorphic core complexes, Cordilleran Orogen, western United States. PhD thesis, School of Earth Sciences, University of Melbourne.

Casas-Sainz, A. M., and Cortes-Gracia, A. L. 2002. Cenozoic landscape development within the Central Iberian Chain, Spain. Geomorphology 44:19-46.

Cavazza, W.; Zattin, M.; Ventura, B.; and Zuffa, G. G. 2001. Apatite fission-track analysis of Neogene exhumation in northern Corsica (France). Terra Nova 13:51-57.

Cherchi, A., and Montadert, L. 1982. Oligo-Miocene rift of Sardinia and the early history of the western Mediterranean basin. Nature 298:736-739.

Clark, M. K.; Royden, L. H.; Whipple, K. X.; Burchfiel, B. C.; Zhang, X.; and Tang, W. 2006. Use of a regional, relict landscape to measure vertical deformation of the eastern Tibetan Plateau. J. Geophys. Res. Earth Surf. 111:F03002, doi:10.1029/2005JF000294.

Cloetingh, S. A. P. L.; Ziegler, P. A.; Beekman, F.; Andriessen, P. A. M.; Hardebol, N.; and Dèzes, P. 2005. Intraplate deformation and 3-D rheological structure of the Rhine Rift System and adjacent areas of the northern Alpine foreland. Int. J. Earth. Sci. 94:758-778.

Cloetingh, S. A. P. L.; Ziegler, P. A.; Bogaard, P. J. F.; Andriessen, P. A. M.; Artemieva, I. M.; Bada, G.; van Balen, R. T.; et al. 2007. TOPO-EUROPE: the geoscience of coupled deep Earth-surface processes. Glob. Planet. Change 58:1-118.

Cocherie, A.; Rossi, P.; and Le Bel, L. 1984. The Variscan calc-alkalic plutonism of western Corsica: mineralogy and major and trace element geochemistry. Phys. Earth Planet. Inter. 35:145-178.

Cubells, J. F.; Ferrandini, J.; Ferrandini, M.; Gaudant, J.; and Loÿe-Pilot M. D. 1994. Présence du genre Aphanius NARDO, famille des Cyprinodontidae, dans le Miocéne du Bassin de Francardo Ponte Leccia (Corse). Geol. Mediterr. 21:19-24.

Danišík, M.; Kuhlemann, J.; Dunkl, I.; Székely, B.; and 
Frisch, W. 2007. Burial and exhumation of Corsica (France) in the light of fission track data. Tectonics 26:TC1001, doi:10.1029/2005TC001938.

Danišík, M.; Migoń, P.; Kuhlemann, J.; Evans, N. J.; Dunkl, I.; and Frisch, W. 2010. Thermochronological constraints on the long-term erosional history of the Karkonosze Mts., central Europe. Geomorphology 117:78-89.

Danišík, M.; Sachsenhofer, R. F.; Privalov, V. A.; Panova, E. A.; Frisch, W.; and Spiegel, C. 2008. Low-temperature thermal evolution of the Azov Massif/Ukrainian Shield-Ukraine): implications for interpreting (U$\mathrm{Th} / \mathrm{He}$ and fission track ages from cratons. Tectonophysics 456:171-179.

Doglioni, C. 1991. A proposal of kinematic modelling for W-dipping subductions: possible applications to the Tyrrhenian-Apennines system. Terra Nova 3:423-434.

Doglioni, C.; Gueguen, E.; Harabaglia, P.; and Mongelli, F. 1999. On the origin of west-directed subduction zones and applications to the western Mediterranean. In Durand, B.; Jolivet, L.; Horváth, F.; and Séranne, M., eds. The Mediterranean basins: Tertiary extension within the Alpine Orogen. Geol. Soc. Spec. Publ. 156: 541-570.

Donelick, R. A.; Ketcham, R. A.; and Carlson, W. D. 1999. Variability of apatite fission-track annealing kinetics: II. Crystallographic orientation effects. Am. Mineral. 84:1224-1234.

Durand-Delga, M. 1978. Corse: guides géologiques régionaux. Masson éd. Paris, 208 p.

1984. Principaux trait de la Corse Alpine et corrélation avec les Alpes ligures. Mem. Soc. Geol. Ital. 28:285-329.

Egal, E. 1992. Structures and tectonic evolution of the external zone of Alpine Corsica. J. Struct. Geol. 14: 1215-1228.

Fairbridge, R. W.; and Finkl, C. W. 1980. Cratonic erosional unconformities and peneplains. J. Geol. 88:69-86.

Farley, K. A. 2000. Helium diffusion from apatite: general behavior as illustrated by Durango fluorapatite. J. Geophys. Res. 105:2903-2914.

- 2002. (U-Th)/He dating: techniques, calibrations, and applications. Mineral. Soc. Am. Rev. Mineral. Geochem. 47:819-844.

Farley, K. A.; Wolf, R. A.; and Silver, L. T. 1996. The effect of long alpha-stopping distances on (U-Th)/He ages. Geochim. Cosmochim. Acta 60:4223-4229.

Fellin, M. G.; Picotti, V.; and Zattin, M. 2005a. Neogene to Quaternary multiple rifting and inversion in northeastern Corsica: retreat and collision in the western Mediterranean. Tectonics 24:TC1011, doi:10.1029/ 2003 TC001613.

Fellin, M. G.; Zattin, M.; Picotti, V.; Reiners, P. W.; and Nicolescu, S. 2005b. Relief evolution in northern Corsica (western Mediterranean): constraints on uplift and erosion at the long-term and short-term time scales. J. Geophys. Res. 110:F01016, doi:10.1029/ 2004JF000167.

Fellin, M. G.; Vance, J.; Garver, J. I.; and Zattin, M. 2006.
The thermal evolution of Corsica as recorded by zircon fission-tracks. Tectonophysics 421:299-317.

Ferrandini, A.; and Loÿe-Pilot, M. D. 1992. Téctonique en distension et décrochement au Burdigalian-Tortonian en Corse: 1'example du bassin Francardo-PonteLeccia (Corse Centrale). Résumés de colloques, sér. spéc., Géologie Alp. 1:30-31.

Ferrandini, M.; Ferrandini, J.; Loÿe-Pilot, M. D.; Butterlin, J.; Cravatte, J.; and Janin, M. C. 1998. Le Miocène du bassin de Saint-Florent (Corse); modalités de la transgression du Burdigalien supérieur et mise en evidence du Serravallien. Geobios 31:125-137.

Ferrandini, L.; Rossi, P.; Ferrandini, M.; Farjanel, G.; Ginsburg, L.; Schuler, M.; and Geissert, F. 1999. La Formation conglomératique du Vazzio près d'Ajaccio (Corse-du-Sud), un témoin des dépôts du Chattien supérieur continental synrift en méditerranée occidentale. Série II, Sciences de la Terre et des Planètes. C. R. Acad. Sci. Paris, 329:271-278.

Flowers, R. M. 2009. Exploiting radiation damage control on apatite (U-Th)/He dates in cratonic regions: Earth Planet. Sci. Lett. 277:148-155.

Flowers, R. M.; and Kelley, S. A. 2011. Interpreting data dispersion and inverted dates in apatite (U-Th)/He and fission-track datasets: an example from the U.S. midcontinent. Geochim. Cosmochim. Acta 75:5169-5186.

Flowers, R. M.; Ketcham, R. A.; Shuster, D. L.; and Farley, K. A. 2009. Apatite (U-Th)/He thermochronometry using a radiation damage accumulation and annealing model. Geochim. Cosmochim. Acta 73:2347-2365.

Flowers, R. M.; Shuster, D. 1.; Wernicke, B. P.; and Farley, K. A. 2007. Radiation damage control on apatite (UTh)/He data from the Grand Canyon, Colorado Region. Geology 35:447-450

Fournier, M.; Jolivet, L.; and Goffé, B. 1991. Alpine Corsica metamorphic core complex. Tectonics 10:1173-1186.

Frisch, W. 1979. Tectonic progradation and plate tectonic evolution of the Alps. Tectonophysics 60:121-139.

Gattacceca, J.; Deino, A.; Rizzo, R.; Jones, D. S.; Henry, B.; Beaudoin, B.; and Vadeboin, F. 2007. Miocene rotation of Sardinia: new paleomagnetic and geochronological constraints and geodynamic implications. Earth Planet. Sci. Lett. 258:359-377.

Gibbons, W., and Horák, J., 1984. Alpine metamorphism of Hercynian hornblende granodiorite beneath the blueschists facies Schistes Lustrés nappe of NE Corsica. J. Metamorph. Geol. 2:95-113.

Gleadow, A. J. W. 1981. Fission track dating methods: what are the real alternatives? Nucl. Tracks Radiat. Meas. 5:3-14.

Gleadow, A. J. W.; Duddy, I. R.; and Green, P. F. 1986. Confined fission track lengths in apatite: a diagnostic tool for thermal history analysis. Contrib. Mineral. Petrol. 94:405-415.

Gleadow, A. J. W.; Duddy, I. R.; and Lovering, J. F. 1983. Fission track analysis: a new tool for the evaluation of thermal history analysis and hydrocarbon potential. Aust. Petrol. Explor. Assoc. J. 23:93-102.

Green, P. F.; and Duddy, I. R. 2006. Interpretation of ap- 
atite $(\mathrm{U}-\mathrm{Th}) / \mathrm{He}$ ages and fission track ages from cratons. Earth Planet. Sci. Lett. 244:541-547.

Green, P. F.; Duddy, I. R.; Laslett, G. M.; Hegarty, K. A.; Gleadow, A. J. W.; and Lovering, J. F. 1989. Thermal annealing of fission tracks in apatite 4. Quantitative modelling techniques and extension to geological timescales. Isot. Geosci. Sect., Chem. Geol. 79:155-182.

Green, P. F.; Crowhurst, P. V.; Duddy, I. R.; Japsen, P.; and Holford, S. P. 2006. Conflicting (U-Th)/He and fission track ages in apatite: enhanced He retention, not anomalous annealing behaviour. Earth Planet. Sci. Lett. 250:407-427.

Gueguen, E.; Doglioni, C.; and Fernandez, M. 1998. On the post-25 Ma geodynamic evolution of the western Mediterranean. Tectonophysics 298:259-269.

Gunnell, Y. 1998. The interaction between geological structure and global tectonics in multistoreyed landscape development: a denudation chronology of the south Indian shield. Basin Res. 10:281-310.

2000. Apatite fission track thermochronology: an overview of its potential and limitations in geomorphology. Basin Res. 12:115-132.

Gunnell, Y.; Calvet, M.; Brichau, S.; Carter, A.; Aguilard, J.-P.; and Zeyen, H. 2009. Low long-term erosion rates in high-energy mountain belts: insights from thermoand biochronology in the eastern Pyrenees. Earth Planet. Sci. Lett. 278:208-218.

Hansen, K., and Reiners, P. W. 2006. Low temperature thermochronology of the southern East Greenland continental margin: evidence from apatite $(\mathrm{U}-\mathrm{Th}) / \mathrm{He}$ and fission track analysis and implications for intermethod calibration. Lithos 92:117-136.

Hendriks, B. W. H., and Redfield, T. F. 2005. Apatite fission track and (U-Th)/He data from Fennoscandia: an example of underestimation of fission track annealing in apatite. Earth Planet. Sci. Lett. 236:443-458.

Herman, F.; Braun, J.; Senden, T.; and Dunlap, W. J. 2007. (U-Th)/He thermochronometry: mapping 3-D geometry using micro-x-ray tomography and solving the associated production-diffusion equation. Chem. Geol. 242:126-136.

Hetzel, R.; Dunkl, I.; Haider, V.; Strobl, M.; von Eynatten, H.; Ding, L.; and Frei, D. 2011. Peneplain formation in southern Tibet predates the India-Asia collision and plateau uplift. Geology 39: 983-986.

Hurford, A. J., and Green, P. F. 1983. The zeta age calibration of fission-track dating. Chem. Geol. 41:285-312.

Jakni, B. 2000. Thermochronologie par traces de fission des marges conjuguées du bassin Liguro-Provençal: la Corse et le massif des Maures-Tanneron. PhD thesis, University Joseph Fourier, Grenoble.

Japsen, P.; Green, P. F.; and Chalmers, J. A. 2005. Separation of Palaeogene and Neogene uplift on Nuussuaq, West Greenland. J. Geol. Soc. Lond. 162:299-314.

Japsen, P.; Bonow, J. M.; Green, P. F.; Chalmers, J. A.; and Lidmar-Bergström, K. 2006. Elevated, passive continental margins: long-term highs or Neogene uplifts: new evidence from West Greenland. Earth Planet. Sci. Lett. 248:315-324.

Japsen, P.; Bonow, J. M.; Green, P. F.; Chalmers, J. A.; and
Lidmar-Bergström, K. 2009. Formation, uplift and dissection of planation surfaces at passive continental margins. Earth Surf. Proc. Land. 34:683-699.

Jolivet, L.; Daniel, J. M.; and Fournier, M. 1991. Geometry and kinematics of ductile extension in Alpine Corsica. Earth Planet. Sci. Lett. 104:278-291.

Jolivet, L.; Dubois, R.; Fournier, M.; Goffé, B.; Michard, A.; and Jourdan, C. 1990. Ductile extension in Alpine Corsica. Geology 18:1007-1010.

Jolivet, L.; Faccenna, C.; Goffé, B.; Mattei, M.; Rosseti, F.; Brunet, C.; Storti, F.; et al. 1998. Midcrustal shear zones in postorogenic extension: example from the Tyrrhenian Sea. J. Geophys. Res. 103:12123-12160.

Ketcham, R. A. 2005. Forward and inversemodeling of low-temperature thermochronometry data. In Reiners, P. W.; and Ehlers, T. A., eds. Low-temperature thermochronology: techniques, interpretations, and applications. Rev. Mineral. Geochem. 58:275-314.

Ketcham, R. A.; Carter, A.; Donelick, R. A.; Barbarand, J.; and Hurford, A. J. 2007. Improved modeling of fissiontrack annealing in apatite. Am. Mineral. 92:799-810.

Ketcham, R. A.; Donelick, R. A.; Balestrieri, M. L.; and Zattin, M. 2009. Reproducibility of apatite fissiontrack length data and thermal history reconstruction. Earth Planet. Sci. Lett. doi:10.1016/j.eps1.2009.05.015.

Kuhlemann, J.; Székely, B.; Frisch, W.; Danišík, M.; Dunkl, I.; Molnár, G.; and Timár, G. 2005. DEM analysis of mountainous relief in a crystalline basement block: Cenozoic relief generations in Corsica (France). Z. Geomorph. 49:1-21.

Lahondère, D., and Guerrot, C. 1997. Datation Nd-Sm du métamorphisme éclogitique en Corse alpine: un argument pour l'existence, au Crétacé supérieur, d'une zone de subduction active localisée le long du bloc corso-sarde. Géol. France 3:3-11.

Lucazeau, F., and Mailhé, D. 1986. Heat flow, heat production and fission track data from the Hercynian basement around the Provençal Basin (western Mediterranean). Tectonophysics 128:335-356.

Mailhé, D.; Lucazeau, F.; and Vasseur, G. 1986. Uplift history of thrust belts: an approach based on fission track data and thermal modelization. Tectonophysics 124:177-191.

Malavieille, J.; Chemenda, A.; and Larroque, C. 1998. Evolutionary model for Alpine Corsica: mechanism for ophiolite emplacement and exhumation of highpressure rocks Terra Nova 10:317-322.

Mattauer, M.; Faure, M.; and Malavieille, J. 1981. Transverse lineation and large scale structures related to Alpine obduction in Corsica. J. Struct. Geol. 3:401-409.

McDowell, F. W.; McIntosh, W. C.; and Farley, K. A. 2005. A precise ${ }^{40} \mathrm{Ar}^{39} \mathrm{Ar}$ reference age for the Durango apatite $(\mathrm{U}-\mathrm{Th}) / \mathrm{He}$ and fission-track dating standard. Chem. Geol. 214:249-263.

Meesters, A. G. C. A., and Dunai, T. J. 2002a. Solving the production-diffusion equation for finite diffusion domains of the various shapes: part 1. Implications for low temperature (U-Th)/He thermochronology. Chem. Geol. 186:333-344.

. $2002 b$. Solving the production-diffusion equation 
for finite diffusion domains of various shapes: part 2 . Application to cases with Alpha ejection and nonhomogeneous distribution of the source. Chem. Geol. 186:345-363.

Mitchell, S. G., and Reiners, P. W. 2003. Influence of wildfires on apatite and zircon $(\mathrm{U}-\mathrm{Th}) / \mathrm{He}$ ages. Geology 31:1025-1028.

Molli, G. 2008. Northern Apennine-Corsica orogenic system: an updated overview. Geol. Soc. Spec. Publ. 298: 413-442.

Orszag-Sperber, F., and Pilot, M.-D. 1976. Grands traits du Néogène de Corse. Bull. Soc. Géol. France 18:11831187.

Penck, W. 1925. Die morphologische analyse. Engelhorn, Stuttgart.

Phillips, J. D. 2002. Erosion, isostatic response, and the missing peneplains. Geomorphology 45:225-241.

Rahn, M. K.; Brandon, M. T.; Batt, G. E.; and Garver, J. I. 2004. A zero-damage model for fission-track annealing in zircon. Am. Mineral, 89:473-484.

Réhault, J.-P.; Boillot, G.; and Mauffret, A. 1984. The western Mediterranean basin geological evolution. Mar. Geol. 55:447-477.

Reiners, P. W.; Thomson, S. N.; McPhillips, D.; Donelick, R. A.; and Roering, J. J. 2007. Wildfire thermochronology and the fate and transport of apatite in hillslope and fluvial environments. J. Geophys. Res. 112: F04001, doi:10.1029/2007JF000759.

Restrepo-Moreno, S. A.; Foster, D. A.; Stockli, D. F.; and Parra-Sanchez, L. N. 2009. Long-term erosion and exhumation of the "Altiplano Antioqueno", northern Andes (Colombia) from apatite (U-Th)/He thermochronology. Earth Planet. Sci. Lett. 278:1-12.

Rondeau, A. 1961. Recherches géomorphologiques en Corse (la part de la téctonique et de l'érosion differentielle dans le relief de l'île). Monographie, 586 p.

Rossi, P., and Cocherie, A. 1991. Genesis of a Variscan batholith: field, petrological and mineralogical evidence from Corsica-Sardinia batholith. Tectonophysics 195:319-346.

Rossi, P.; Rouire, J.; and Durand-Delga, M. 1980. Carte géologique de la France. A 1/250 000, Corse, sheet 44/ 45, Notice explicative de la feuille. BRGM, Orléans, $80 \mathrm{p}$.

Sérrane, M. 1999. The Gulf of Lion continental margin (NW Mediterranean) revisited by IBS: an overview. In Durand, B.; Jolivet, L.; Horváth, F.; and Séranne, M., eds. The Mediterranean basins: Tertiary extension within the Alpine Orogen. Geol. Soc. Spec. Publ. 156: 15-36.

Shuster, D. L.; Flowers, R. M.; and Farley, K. A. 2006. The influence of natural radiation damage on helium diffusion kinetics in apatite. Earth Planet. Sci. Lett. 249:148-161.

Spiegel, C.; Kohn, B. P.; Belton, D. X.; and Gleadow, A. J. W. 2007. Morphotectonic evolution of the central
Kenya rift flanks: implications for late Cenozoic environmental change in east Africa. Geology 35:427430.

Stockli, D.; Farley, K. A.; and Dumitru, T. 2000. Calibration of the (U-Th)/He thermochronometer on an exhumed fault block in the White Mountains, eastern California and western Nevada. Geology 28:983-986.

Summerfield, M. A. 2000. Geomorphology and global tectonics: introduction. In Summerfield, M. A., ed. Geomorphology and global tectonics. Wiley, Chichester, p. 3-12.

- 2005. The changing landscape of geomorphology. Earth Surf. Proc. Land. 30:779-781.

Tagami, T. 2005. Zircon fission-track thermochronology and applications to fault studies. In Reiners, P. W.; and Ehlers, T. A., eds. Low-temperature thermochronology: techniques, interpretations, and applications. Rev. Mineral. Geochem. 58:95-122.

Twidale, C. R. 1994. Gondwanan (Late Jurassic and Cretaceous) palaeosurfaces of the Australian craton. Palaeogeogr. Palaeoclimatol. Palaeoecol. 112:157-186.

- 1998. Antiquity of landforms: an "extremely unlikely" concept vindicated. Austral. J. Earth Sci. 45: 657-668.

. 1999. Landforms ancient and recent: the paradox. Geogr. Ann. Ser. A: Phys. Geogr. 81:431-441.

Vigliotti, L., and Langenheim, V. E. 1995. When did Sardinia stop rotating? new paleomagnetic results. Terra Nova 7:424-435.

Vigliotti, L.; Alvarez, W.; and McWilliams, M. 1990. No relative motion detected between Corsica and Sardinia. Earth Planet. Sci. Lett. 98:313-318.

Wagner, G. A.; and Van den haute, P. 1992. Fission-track dating. Enke, Stuttgart, 285 p.

Watchman, A. L.; and Twidale, C. R. 2002. Relative and "absolute" dating of land surfaces. Earth Sci. Rev. 58: $1-49$.

Wolf, R. A.; Farley, K. A.; and Kass, D. M. 1998. A sensitivity analysis of the apatite (U-Th)/He thermochronometer. Chem. Geol. 148:105-114.

Yamada, R.; Tagami, T.; Nishimura, S.; and Ito, H. $1995 a$. Annealing kinetics of fission tracks in zircon: an experimental study. Chem. Geol. 119:293-306.

- 1995b. Annealing kinetics of fission tracks in zircon: an experimental study. Chem. Geol. 122:249-258.

Zarki-Jakni, B.; Van der Beek, P.; Poupeau, G.; Sosson, M.; Labrin, E.; Rossi, P.; and Ferrandini, J. 2004. Cenozoic denudation of Corsica in response to Ligurian and Tyrrhenian extension: results from apatite fissiontrack thermochronology. Tectonics 23:TC1003, doi: 10.1029/2003TC001535.

Zeitler, P. K.; Herczig, A. L.; McDougall, I.; and Honda, M. 1987. U-Th-He dating of apatite: a potential thermochronometer. Geochim. Cosmochim. Acta 51: 2865-2868. 